\title{
Effect of Prepartum Photoperiod on Milk Production and Prolactin Concentration of Dairy Ewes
}

\author{
C. M. Mikolayunas, ${ }^{\star 1}$ D. L. Thomas, ${ }^{*}$ G. E. Dahl,$\dagger^{2}$ T. F. Gressley, $\dagger^{3}$ and Y. M. Berger $\ddagger$ \\ *Department of Animal Sciences, University of Wisconsin-Madison, Madison 53706 \\ †Department of Animal Sciences, University of Illinois, Urbana 61801 \\ ¥Spooner Agricultural Research Station, University of Wisconsin-Madison, Spooner 54801
}

\section{ABSTRACT}

Long photoperiods during established lactation increase milk production in dairy cattle and dairy sheep, but recent research in cattle and dairy goats suggests an additional influence of prepartum day length on milk yield in the subsequent lactation. The proposed mechanism of function is the level and role of circulating prolactin in mammary development. The objectives of this study were to evaluate the effect of prepartum photoperiod on milk production, milk composition, and prolactin concentration of 22 multiparous dairy ewes exposed to short day prepartum photoperiod (SDPP; $8 \mathrm{~h}$ of light:16 h of dark) or long day prepartum photoperiod (LDPP; $16 \mathrm{~h}$ of light:8 $\mathrm{h}$ of dark) for at least $6 \mathrm{wk}$ prepartum. During the first 8 wk of lactation, SDPP ewes tended to produce more milk than LDPP ewes ( $2.43 \mathrm{vs.} .2 .29 \mathrm{~kg} / \mathrm{d}$, respectively), and the milk of SDPP ewes had a greater fat percentage than that of LDPP ewes (6.04 vs. $5.51 \%$, respectively). Due to daily milk yield and greater fat content, SDPP ewes produced more $6.5 \%$ fat-corrected milk $(+0.30 \pm 0.08 \mathrm{~kg} / \mathrm{d})$ and $6.5 \%$ fat- and $5.8 \%$ protein-corrected milk $(+0.28 \pm 0.08$ $\mathrm{kg} / \mathrm{d}$ ) than LDPP ewes. For the lactation period of 180 $\mathrm{d}$, SDPP ewes produced more test day milk than LDPP ewes ( 1.76 vs. $1.60 \pm 0.05 \mathrm{~kg} / \mathrm{d}$, respectively), but there were no differences in milk fat or protein percentages. Ewes in both treatments experienced a prolactin surge at lambing, but SDPP ewes had lower circulating prolactin concentration than LDPP ewes from 4 to $0.5 \mathrm{wk}$ before lambing ( 14.7 vs. $51.3 \pm 4.2 \mathrm{mg} / \mathrm{dL}$, respectively). These data suggest that decreased prepartum photoperiod may be important for increasing milk production in dairy ewes and may provide a management strategy for dairy sheep producers to increase milk yield.

Received August 7, 2007.

Accepted May 28, 2007.

${ }^{1}$ Corresponding author: mikolayunas@wisc.edu

${ }^{2}$ Current address: Department of Animal Sciences, University of Florida, Gainesville 32611.

${ }^{3}$ Current address: Department of Animal and Food Sciences, University of Delaware, Newark 19716.
Key words: dairy sheep, milk yield, photoperiod, prolactin

\section{INTRODUCTION}

Seasonal changes in day length (i.e., photoperiod) regulate many aspects of mammalian physiology, including reproduction (Ortavant et al., 1988), fattening (Forbes, 1982), pelage growth (Lincoln and Baker, 1995), and tissue growth (Forbes, 1982). There is evidence that photoperiod affects milk production. Previous work with dairy cows (Peters et al., 1978; Dahl et al., 2000) and dairy sheep (Bocquier et al., 1997) indicated that, once lactation is established, exposure to long day photoperiod increases milk production. More recent work in dairy cattle and dairy goats suggests that prepartum photoperiod affects mammary development and subsequent milk production, but the positive response is from short day photoperiod. Cows experiencing short day photoperiod ( $8 \mathrm{~h}$ of light:16 $\mathrm{h}$ of dark) for 60 d (Miller et al., 2000; Auchtung et al., 2005) or 42 d (Velasco et al., 2006) prepartum had greater milk yields than cows experiencing long day photoperiod (16 $\mathrm{h}$ of light: $8 \mathrm{~h}$ of dark). The proposed mechanism of function is the level and role of circulating prolactin (PRL) in mammary development; previous work supports an inverse relationship between circulating PRL concentration and the expression of PRL receptor mRNA in the mammary tissue of cows (Auchtung et al., 2005). Cows experiencing short day prepartum photoperiod (SDPP) had increased expression of PRL receptor mRNA, possibly resulting in greater sensitivity to the periparturient PRL surge and enhanced proliferation and survival of mammary cells (Auchtung et al., 2005; Wall et al., 2005). This study was conducted to determine the difference in milk production, milk composition, and circulating PRL concentration of ewes exposed to short days or long days for approximately $6 \mathrm{wk}$ prepartum. 


\section{MATERIALS AND METHODS}

\section{Ewes}

The study was conducted at the University of Wisconsin-Madison campus and the University's Spooner Agricultural Research Station. All procedures were approved by the Animal Care and Use Committee of the College of Agriculture and Life Sciences. Twenty-two multiparous 4-yr-old dairy ewes were randomly assigned to 1 of 2 photoperiod treatments: long day prepartum photoperiod (LDPP; $16 \mathrm{~h}$ of light:8 h of dark; $\mathrm{n}=11$ ) or short day prepartum photoperiod ( 8 of $h$ light:16 h of dark; $n=11$ ). Milk production, milk fat, and milk protein percentages for the previous year were not significantly different between ewes on the SDPP and LDPP treatments (272.3 vs. $259.3 \pm 9.9 \mathrm{~kg}$ of milk, 5.2 vs. $5.0 \pm 0.2 \%$ fat, and 4.3 vs. $4.3 \pm 0.1 \%$ protein, respectively).

Prepartum photoperiod treatments began on December 20, 2005 and were applied for a minimum of $44 \mathrm{~d}$ and an average of $54 \mathrm{~d}$ ( $\pm 6 \mathrm{~d}$ for SDPP; $\pm 11 \mathrm{~d}$ for LDPP). Ewes on the SDPP and LDPP treatments were housed in 2 different but adjacent rooms with the same dimensions ( $3 \mathrm{~m} \times 8.8 \mathrm{~m})$, layout, and climate-controlled environment $\left(17^{\circ} \mathrm{C}\right.$ and 30 to $70 \%$ relative humidity) on the Madison campus. Light exposure was $365 \mathrm{~lx}$ at sheepeye level ( $0.76 \mathrm{~m}$ above the floor) and was provided by fluorescent lights and controlled by an automatic timer. Lights were turned on at $0700 \mathrm{~h}$ daily and turned off at 1500 and $2300 \mathrm{~h}$ for the SDPP and LDPP treatments, respectively. After parturition, lambs were removed within $12 \mathrm{~h}$ of lambing, and ewes were moved from photoperiod treatment rooms to the milking room within the same building with a photoperiod of $12 \mathrm{~h}$ of light and $12 \mathrm{~h}$ of dark. Ewes were machine-milked within $12 \mathrm{~h}$ of lambing and were subsequently milked twice daily at approximately 0700 and $1700 \mathrm{~h}$. Four SDPP ewes experienced hoof problems related to the flooring in the light treatment room and were moved to the milking room 6 to $9 \mathrm{~d}$ before lambing, and blood PRL data from these ewes during this time period were removed from the analysis. Milk production and milk composition data from these ewes remained in the analyses.

The trial period, when ewes were milked in the controlled light environment, lasted from lambing until April 10, 2006. Due to variations in lambing date, trial DIM ranged from 43 to $61 \mathrm{~d}$ for SDPP ewes and from 30 to $64 \mathrm{~d}$ for LDPP ewes but averaged $53 \pm 3 \mathrm{~d}$ for both treatment groups. Ewes were moved to the Spooner Agricultural Research Station (Spooner, WI), integrated into the resident milking flock, and exposed to natural photoperiod ( $13 \mathrm{~h} 16 \mathrm{~min}$ of light/d) on April 6 , 2006. Ewes were managed in the light-controlled
Table 1. Composition of alfalfa haylage fed to ewes during prepartum and trial period

\begin{tabular}{lc}
\hline Nutrient & DM, \% \\
\hline NDF & 48.0 \\
NFC & 22.8 \\
CP & 17.5 \\
Ash & \\
Fat & 8.5 \\
\hline
\end{tabular}

${ }^{1} \mathrm{Ash}=100-(\mathrm{NDF}+\mathrm{CP}+\mathrm{NFC}+$ fat +1$)$.

environment on campus after lambing rather than being sent directly to the Spooner Station to facilitate easy access by the researchers to the animals for data collection during early lactation and to avoid the stress of shipment immediately after lambing. The posttrial period, when ewes were managed with the Spooner flock, lasted until August 8 ( $\mathrm{n}=21 ; 14 \mathrm{~h} 28$ min of light/ d) or September 6, 2006 ( $\mathrm{n}=1 ; 13 \mathrm{~h} 2 \mathrm{~min}$ of light/d). The trial plus posttrial period includes milk production and milk composition data until $180 \pm 6$ DIM.

During the prepartum and trial periods, ewes were fed ad libitum alfalfa silage and $0.9 \mathrm{~kg} / \mathrm{d}$ of whole shelled corn. Composition of the alfalfa haylage is presented in Table 1 . The daily corn supplement was divided into 2 equal portions and fed in the milking parlor at each of the 2 daily milkings. Ewes had ad libitum access to minerals and water. During the posttrial period at the Spooner Agricultural Research Station, all ewes were group-fed $1.9 \mathrm{~kg}$ of DM/d of alfalfa haylage in the drylot before the start of the pasture season and individually fed $0.9 \mathrm{~kg} / \mathrm{d}$ of whole shelled corn in the milking parlor. All ewes were moved to pasture on May 16 and continued to receive corn in the milking parlor. Haylage feeding was initially discontinued when the ewes went to pasture (79 \pm 3 DIM), but due to a summer drought, haylage feeding was resumed in midsummer (123 \pm 3 DIM).

\section{Data and Sample Collection}

During the trial period, daily milk production for individual ewes was measured twice weekly using a graduated Waikato Goat Meter (Waikato Milking Systems NZ Ltd., Hamilton, New Zealand) by combining the amount of milk obtained at an evening and subsequent morning milking. Weekly milk samples from the morning milking were analyzed for percentage of fat and percentage of protein (AgSource Milk Labs, Stratford, WI). Test day milk production was adjusted to $6.5 \% \mathrm{FCM}$ and $6.5 \%$ fat and $5.8 \%$ protein-corrected milk (FPCM), based on the following equations developed by Pulina et al. (1989): 
Table 2. Average daily milk production and milk composition (mean \pm SEM) of ewes exposed to different prepartum photoperiod treatments during the trial period (to 53 DIM) and the trial plus posttrial period (to 180 DIM)

\begin{tabular}{lccccccc}
\hline & \multicolumn{3}{c}{ Trial period } & & \multicolumn{2}{c}{ Trial and posttrial period } \\
\cline { 2 - 4 } Trait & SDPP $^{1}$ & LDPP $^{2}$ & $P$ & & SDPP & LDPP & $P$ \\
\hline Milk, kg/d & $2.43 \pm 0.051$ & $2.29 \pm 0.051$ & 0.0534 & & $1.76 \pm 0.051$ & $1.60 \pm 0.050$ & 0.0309 \\
Fat, $\%$ & $6.04 \pm 0.102$ & $5.51 \pm 0.104$ & 0.0003 & & $6.28 \pm 0.110$ & $6.48 \pm 0.107$ & 0.2162 \\
Protein, $\%$ & $4.61 \pm 0.057$ & $4.54 \pm 0.057$ & 0.4485 & & $5.23 \pm 0.064$ & $5.12 \pm 0.062$ & 0.2408 \\
FCM, ${ }^{3} \mathrm{~kg} / \mathrm{d}$ & $2.36 \pm 0.060$ & $2.06 \pm 0.060$ & 0.0006 & & $1.69 \pm 0.048$ & $1.55 \pm 0.047$ & 0.0437 \\
FPCM $^{4}{ }^{4} \mathrm{~kg} / \mathrm{d}$ & $2.28 \pm 0.058$ & $2.00 \pm 0.057$ & 0.0006 & & $1.66 \pm 0.048$ & $1.52 \pm 0.046$ & 0.0340 \\
\hline
\end{tabular}

${ }^{1}$ Short day prepartum photoperiod ( $8 \mathrm{~h}$ of light:16 h of dark), $\mathrm{n}=11$.

${ }^{2}$ Long day prepartum photoperiod ( $16 \mathrm{~h}$ of light: $8 \mathrm{~h}$ of dark), $\mathrm{n}=11$.

${ }^{3} 6.5 \%$ FCM.

${ }^{4} 6.5 \%$ fat- and $5.8 \%$ protein-corrected milk.

$$
\begin{gathered}
\mathrm{FCM}=\mathrm{M}[0.37+(0.097 \times \mathrm{F})] \\
\mathrm{FPCM}=\mathrm{M}[0.25+(0.085 \times \mathrm{F})+(0.035 \times \mathrm{P})]
\end{gathered}
$$

where $\mathrm{M}=$ milk yield $(\mathrm{kg})$ and $\mathrm{F}$ and $\mathrm{P}=$ fat and protein concentration (\%), respectively. Once ewes moved to the Spooner Agricultural Research Station, milk production and milk composition data were recorded monthly for the remainder of the lactation.

Blood samples (20 mL/ewe) were collected from each ewe from 0800 to $1000 \mathrm{~h}$ via the jugular vein twice weekly from December 16, 2005 until 1 wk postpartum. Blood samples were collected into two 10-mL sterile evacuated tubes containing sodium heparin and imme- diately put on ice. Plasma was harvested by centrifugation at $1,850 \times g$ for $20 \mathrm{~min}$ at $4^{\circ} \mathrm{C}$ within $1 \mathrm{~h}$ of collection. Plasma was stored at $-20^{\circ} \mathrm{C}$ and analyzed using the PRL RIA, as described by Miller et al. (1999). Mean intra- and interassay CV (2 assays) were 9.5 and $7.1 \%$, respectively. Assay sensitivity was $0.73 \mathrm{ng} / \mathrm{mL}$.

\section{Statistical Analysis}

Milk production, milk composition, and PRL concentrations were analyzed using the MIXED procedure of SAS (Version 8.2, SAS Institute Inc., Cary, NC). The model included the fixed effects of photoperiod treatment, day or week of lactation, their interaction, the

\begin{tabular}{ccccccccccccccc} 
DIM & 5 & 9 & 12 & 16 & 19 & 23 & 26 & 30 & 34 & 37 & 41 & 44 & 47 & 53 \\
\cline { 2 - 12 } SDPP, n & 11 & 11 & 11 & 11 & 11 & 11 & 11 & 11 & 11 & 11 & 11 & 11 & 10 & 8 \\
LDPP, n & 11 & 11 & 11 & 11 & 11 & 11 & 11 & 11 & 10 & 10 & 9 & 9 & 9 & 8
\end{tabular}

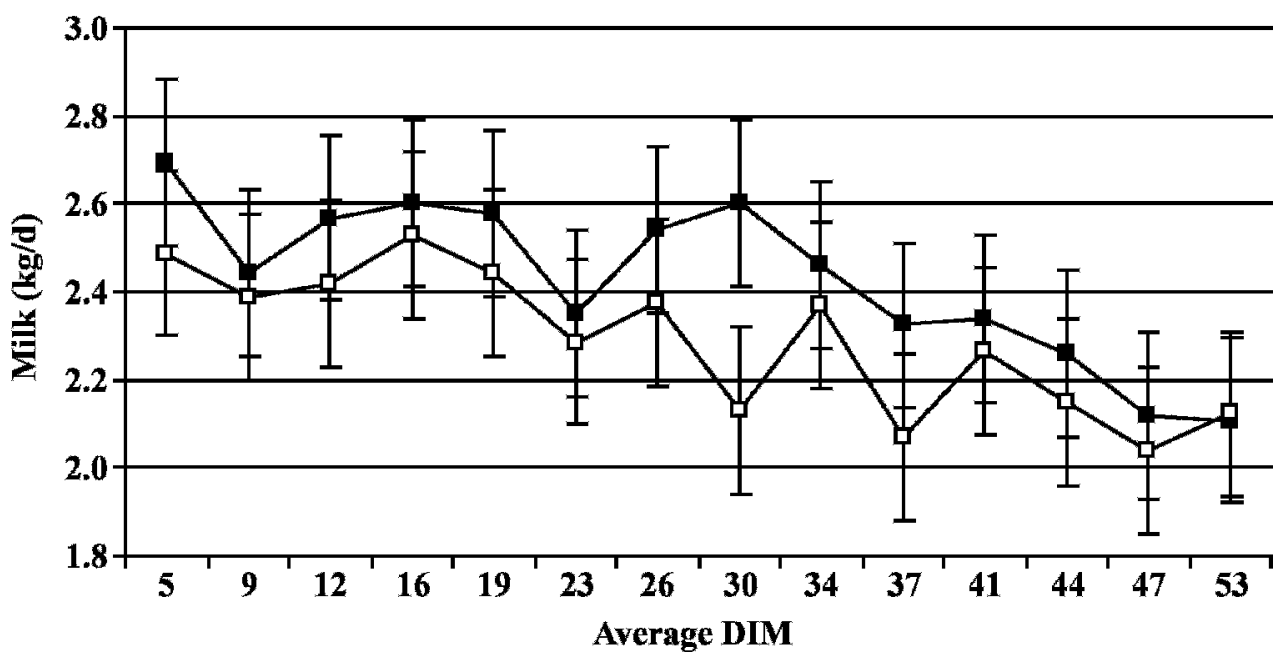

Figure 1. Mean test day milk yield during the trial period of ewes exposed to short day prepartum photoperiod (SDPP; $8 \mathrm{~h}$ of light:16 $\mathrm{h}$ of dark; ) or long day prepartum photoperiod (LDPP; $16 \mathrm{~h}$ of light:8 $\mathrm{h}$ of dark; $\square$ ). The table presents the number of ewes per treatment (n) on each test day relative to DIM. Error bars indicate SEM. 
random effects of ewe and residual, and an autoregressive covariate for repeated measures on each ewe. Separate analyses were conducted on data collected during the trial period and the trial plus posttrial periods. Trial period data included biweekly milk production and milk composition data, whereas the trial plus posttrial milk yield analysis included monthly milk yield and composition data. Pretrial hormone concentration was used as a covariate in analysis of PRL concentration. None of the treatment $\times$ time interactions were significant for milk production and milk composition. All values presented are least squares means and standard errors of the mean, and significant differences between least squares means were declared at $P<0.05$ unless otherwise noted.

\section{RESULTS AND DISCUSSION}

\section{Milk Production and Composition}

Dairy ewes experiencing SDPP for at least $6 \mathrm{wk}$ prepartum produced $0.14 \pm 0.07 \mathrm{~kg} / \mathrm{d}$ more $(P=0.053)$ milk than LDPP ewes $(2.43 \mathrm{vs} .2 .29 \mathrm{~kg} / \mathrm{d}$, respectively; Table 2 ) during the trial period. Individual test day milk yield of treatments is shown in Figure 1. Average daily milk production for the trial period when ewes were in the confined, controlled light facility plus the posttrial period when ewes were managed on pasture at the Spooner Agricultural Research Station is presented in Table 2. During 180 DIM, SDPP ewes produced $0.16 \mathrm{~kg} / \mathrm{d}$ more $(P<0.05)$ milk than LDPP ewes $(1.76$ vs. $1.60 \pm 0.05 \mathrm{~kg} /$ $\mathrm{d}$, respectively).

During the trial period, daily milk fat percentage was greater $(P<0.001)$ in SDPP ewes than LDPP ewes $(6.04$ vs. $5.51 \pm 0.10 \%$, respectively). Individual test day values for milk fat percentage are in Figure 2. During the trial period, there were no significant differences between SDPP and LDPP treatments for milk protein percentage (Table 2, Figure 2). Due to daily milk production and greater milk fat percentage, SDPP ewes produced more FCM $(+0.30 \pm 0.08 \mathrm{~kg} / \mathrm{d} ; P<0.001)$ and FPCM $(+0.28 \pm$ $0.08 \mathrm{~kg} / \mathrm{d} ; P<0.001)$ than LDPP during the trial period (Table 2).

When data from the trial period were combined with data from the posttrial period, there were no significant differences between the prepartum light treatments for milk fat and protein percentages (Table 2) during 180 DIM. Yet, SDPP ewes produced more $(P<0.05)$ daily FCM $(+0.14 \pm 0.05 \mathrm{~kg} / \mathrm{d})$ and FPCM $(+0.14 \pm 0.05 \mathrm{~kg} / \mathrm{d})$ than LDPP ewes during the entire period.

In the present study, milk fat percentage in early lactation was greater for SDPP ewes relative to those on LDPP. In dairy cows, there was no observed effect of prepartum photoperiod treatment on milk fat percentage (Miller et al., 2000; Auchtung et al., 2005), and dairy

\begin{tabular}{lcccccccc} 
Week & 1 & $\mathbf{2}$ & $\mathbf{3}$ & $\mathbf{4}$ & $\mathbf{5}$ & $\mathbf{6}$ & $\mathbf{7}$ & $\mathbf{8}$ \\
\hline SDPP, n & 11 & $\mathbf{1 1}$ & $\mathbf{1 1}$ & $\mathbf{1 1}$ & $\mathbf{1 1}$ & $\mathbf{1 1}$ & $\mathbf{1 0}$ & 7 \\
I.DPP, n & 11 & $\mathbf{1 1}$ & $\mathbf{1 1}$ & $\mathbf{1 0}$ & $\mathbf{1 0}$ & $\mathbf{9}$ & $\mathbf{9}$ & $\mathbf{8}$
\end{tabular}
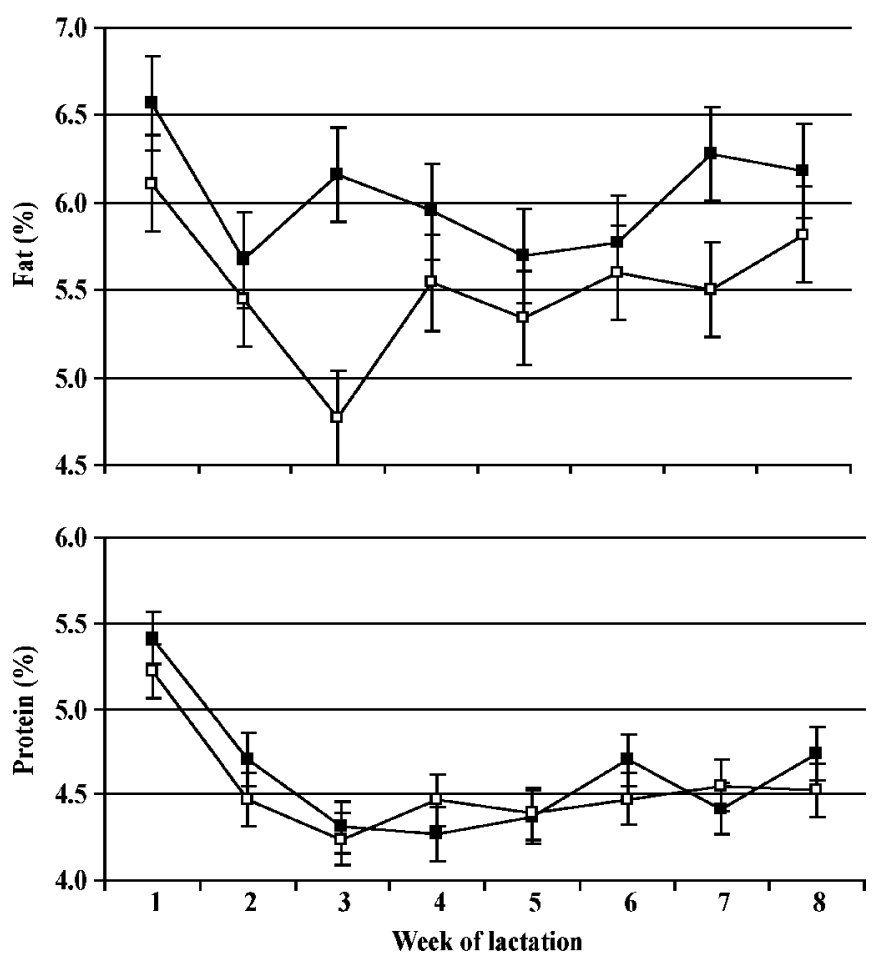

Figure 2. Mean fat and protein percentage during the trial period of ewes exposed to short day prepartum photoperiod (SDPP; $8 \mathrm{~h}$ of light:16 h of dark; $\mathbf{E})$ or long day prepartum photoperiod (LDPP; 16 $\mathrm{h}$ of light: $8 \mathrm{~h}$ of dark; $\square)$. The table presents the number of ewes per treatment (n) relative to week of lactation. Error bars indicate SEM.

does exposed to SDPP had lower milk fat percentage than LDPP does (Mabjeesh et al., 2007). The reasons for the differential response of milk fat to prepartum light treatment in these 3 species is not known.

The observed effect of SDPP prepartum on subsequent milk production may have contributed to the reported increase in annual milk production of dairy ewes at the Spooner Agricultural Research Station from 1996 to 2004 (Berger, 2005). In an analysis of factors contributing to this progress, there were effects of dairy genetics, breed composition, and weaning system, findings that support previous authors (Bencini and Pulina, 1997; McKusick et al., 2001). Some of the increase in milk production was attributed to lambing month. The start of the lambing season gradually moved from April to late January. Ewes were milking during the increasing day length of spring and summer and were likely responding to the known positive effects of increasing photoperiod during lactation on milk production (Bocquier et al., 1997). In addition, January and February lambing ewes were experiencing shortened prepartum photoperi- 


\begin{tabular}{llllcccccc} 
Week & -5 & -4 & -3 & -2 & -1 & -0.5 & 0 & 0.5 & 1 \\
\hline SDPP, n & 10 & 10 & 10 & 10 & 7 & 7 & 7 & 10 & 10 \\
LDPP, n & 10 & 10 & 10 & 10 & 10 & 10 & 8 & 10 & 9
\end{tabular}

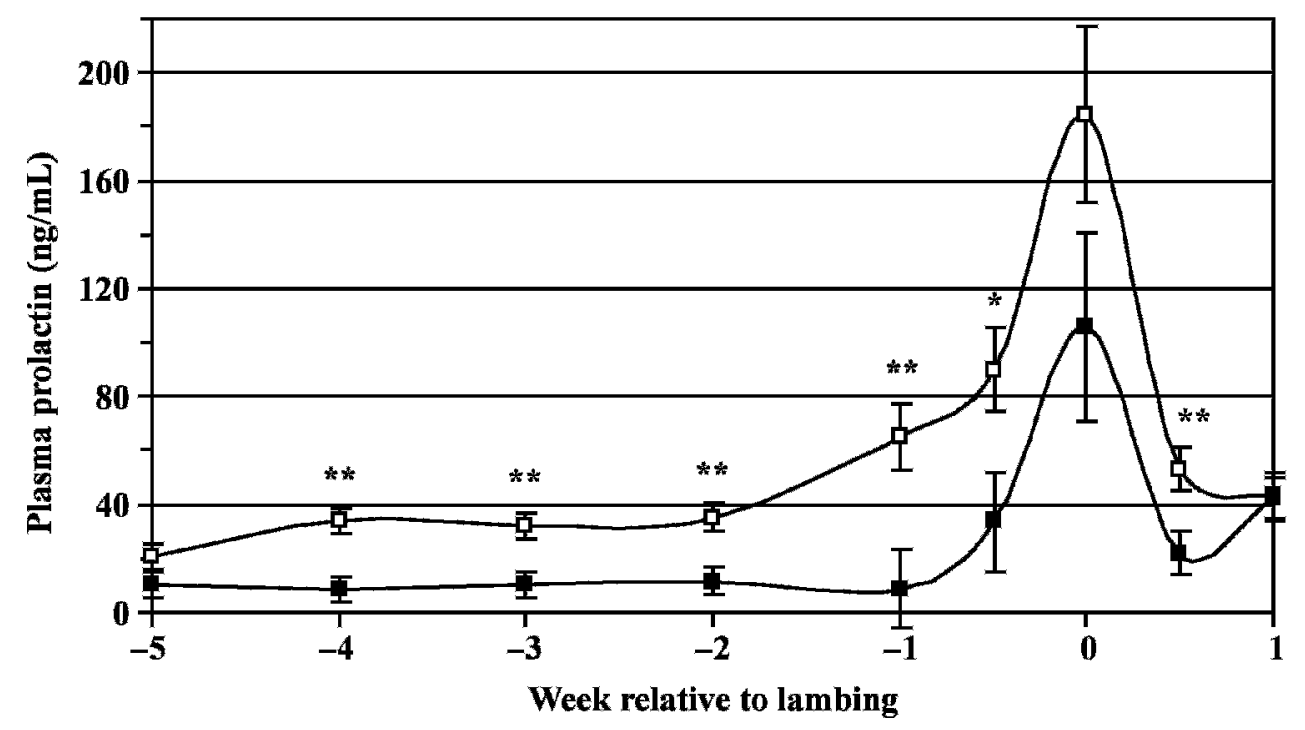

Figure 3. Mean concentration of plasma prolactin of ewes exposed to short day prepartum photoperiod (SDPP; 8 h of light:16 h of dark; - ) or long day prepartum photoperiod (LDPP; $16 \mathrm{~h}$ of light: $8 \mathrm{~h}$ of dark; $\square$ ). The table presents the number of ewes per treatment (n) on each week relative to lambing. Error bars indicate SEM. *Least squares means within a test day are different $(P<0.05)$.**Least squares means within a test day are different $(P<0.01)$.

ods compared with March and April lambing ewes, which may be an additional factor in increasing milk yield.

\section{PRL}

The pattern for prepartum PRL concentration observed in the dairy ewes is in Figure 3. Circulating PRL concentrations were lower $(P<0.05)$ for SDPP ewes than for LDPP ewes from 4 to 0.5 wk before lambing. Prolactin concentrations returned to similar concentrations by 1 wk after parturition.

Studies with dairy cattle suggest that prepartum photoperiod effects are due to circulating PRL concentration, which influences the number or sensitivity of PRL receptors on mammary secretory epithelial cells. There was an inverse relationship between circulating PRL concentration and the expression of PRL receptor mRNA in the liver, lymphocytes, and mammary tissue of cows (Auchtung et al., 2005). Auchtung et al. (2005) found that cows exposed to short days for $60 \mathrm{~d}$ prepartum had lower concentrations of circulating PRL than those exposed to long days at both 33 and $5 \mathrm{~d}$ before calving. Prolactin returned to similar levels within $2 \mathrm{~d}$ after calving.

Work by Akers et al. (1981) demonstrated that PRL secretion at parturition stimulates mammary differenti- ation and influences milk synthesis in dairy cattle. Therefore, a possible cascade of events to describe the effect of prepartum photoperiod on milk production may be as follows: 1) short photoperiod in prepartum ruminants results in decreased circulating PRL concentrations; 2) decreased PRL stimulates the increased expression of mRNA for PRL receptors, resulting in a greater number of PRL receptors on mammary secretory epithelial cells; and 3) the natural increase in circulating PRL at parturition stimulates more extensive differentiation and commitment of mammary secretory epithelial cells to produce lactose, thereby increasing milk production in SDPP-treated animals.

\section{CONCLUSIONS}

Dairy ewes exposed to SDPP for at least 6 wk prepartum produced more FCM than ewes exposed to LDPP. The prepartum treatment of short day length resulted in a decrease in prepartum circulating PRL concentrations, which may contribute to increased sensitivity of the mammary gland to circulating PRL and an increase in milk production in the subsequent lactation. This may have implications for dairy sheep flocks, most of which lamb once per year. Dairy ewes in late pregnancy during times of the year with shorter day length (i.e., 
winter) might be expected to produce more FCM than ewes in late pregnancy during times of the year with longer day length (i.e., spring). Berger (2005) reported greater milk production from dairy ewes lambing in January than from ewes lambing in April, and prepartum photoperiod may be one of the factors influencing this difference.

\section{REFERENCES}

Akers, R. M., D. E. Bauman, A. V. Capuco, G. T. Goodman, and H. A. Tucker. 1981. Prolactin regulation of milk secretion and biochemical differentiation of mammary epithelial cells in periparturient cows. Endocrinology 109:23-30.

Auchtung, T. L., A. G. Rius, P. E. Kendall, T. B. McFadden, and G. E. Dahl. 2005. Effects of photoperiod during the dry period on prolactin, prolactin receptor, and milk production of dairy cows. J. Dairy Sci. 88:121-127.

Bencini, R., and G. Pulina. 1997. The quality of sheep milk: A review. Aust. J. Exp. Agric. 37:485-504.

Berger, Y. M. 2005. Evolution of milk production at the Spooner Agricultural Research Station between 1996 and 2004. Pages 613 in Proc. 11th Annu. Great Lakes Dairy Sheep Symp. Cornell Univ. Dept. Anim. Sci., Univ. Wisc.-Madison, Dept. Anim. Sci., and Univ. Vermont Ctr. Sustainable Agric.

Bocquier, F., S. Ligios, G. Molle, and S. Casu. 1997. Effect of photoperiod on milk, milk composition and voluntary food intake in lactating dairy ewes. Ann. Zootech. (Paris) 46:427-438.

Dahl, G. E., B. A. Buchanan, and H. A. Tucker. 2000. Photoperiodic effects on dairy cattle: A review. J. Dairy Sci. 83:885-893.

Forbes, J. M. 1982. Effects of lighting pattern on growth, lactation and food-intake of sheep, cattle and deer. Livest. Prod. Sci. 9:361-374.
Lincoln, G. A., and B. I. Baker. 1995. Seasonal and photoperiodinduced changes in the secretion of $\alpha$-melanocyte-stimulating hormone in Soay sheep - temporal relationships with changes in $\beta$ endorphin, prolactin, follicle-stimulating-hormone, activity of the gonads and growth of wool and horns. J. Endocrinol. 144:471-481.

Mabjeesh, S. J., O. Gal-Garber, and A. Shamay. 2007. Effect of photoperiod in the third trimester of gestation on milk production and circulating hormones in dairy goats. J. Dairy Sci. 90:699-705.

McKusick, B. C., D. L. Thomas, and Y. M. Berger. 2001. Effect of weaning system on commercial milk production and lamb growth of East Friesian dairy sheep. J. Dairy Sci. 84:1660-1668.

Miller, A. R. E., L. W. Douglass, R. A. Erdman, and G. E. Dahl. 2000. Effects of photoperiodic manipulation during the dry period of dairy cows. J. Dairy Sci. 83:962-967.

Miller, A. R. E., E. P. Stanisiewski, R. A. Erdman, L. W. Douglass, and G. E. Dahl. 1999. Effects of long daily photoperiod and bovine somatotropin $\left(\right.$ Trobest $^{\circledR}$ ) on milk yield in cows. J. Dairy Sci. 82:1716-1722.

Ortavant, R., F. Bocquier, J. Pelletier, J. P. Ravault, J. Thimonier, and N. P. Volland. 1988. Seasonality of reproduction in sheep and its control by photoperiod. Aust. J. Biol. Sci. 41:69-86.

Peters, R. R., L. T. Chapin, K. B. Leining, and H. A. Tucker. 1978. Supplemental lighting stimulates growth and lactation in cattle. Science 199:911-912.

Pulina, G., A. Serre, A. Cannas, and G. Rossi. 1989. Determinazione e stima del valore energetico di latte di pecore di razza sarda. (Measurement and prediction of energetic value of milk of Sarda ewes). Atti Soc. Ital. Sci. Vet. 43:1867-1870.

Velasco, J. M., E. D. Reid, K. E. Karvetski, T. F. Gressley, R. L. Wallace, and G. E. Dahl. 2006. Short day photoperiod increases milk yield in cows with a reduced dry period length. J. Anim. Sci. 84(Suppl. 1):147. (Abstr.)

Wall, E. H., T. L. Auchtung, G. E. Dahl, S. E. Ellis, and T. B. McFadden. 2005. Exposure to short day photoperiod during the dry period enhances mammary growth in dairy cows. J. Dairy Sci. 88:1994-2003. 